Krzysztof Wawrzonkowski

Uniwersytet Mikołaja Kopernika, Toruń

ORCID: 0000-0003-2792-1312

e-mail:kwawrzonkowski@umk.pl

\title{
Rola rozumu w koncepcji estetycznej Alexandra Gerarda
}

Niniejszy artykuł jest poświęcony koncepcji estetycznej Alexandra Gerarda (1728-1795) i roli, jaką przewidział w niej dla rozumu (ratio) i wydawanych przez niego sądów (judgments). Dla lepszego zrozumienia doniosłości i znaczenia rozważań filozofa przedstawiam je w szerszym kontekście na tle osiemnastowiecznej estetyki brytyjskiej. Nie jest to zadanie łatwe, ówczesna estetyka nie była bowiem jednorodna. Ze względu na ramy objętościowe tekstu jestem zmuszony poprzestać na pewnych dotyczących jej uogólnieniach i wskazać najważniejsze z podejmowanych wówczas problemów, panujących tendencji i zarysowujących się osi sporów ${ }^{1}$. Ułatwiając sobie nieco owo zadanie, skoncentruję

${ }^{1}$ Szersze przedstawienie interesującego nas tu zagadnienia, a także szczegółowe omówienie konkretnych ówczesnych teorii estetycznych (Shaftesbury, Joseph Addison, David Hume, Edmund Burke, Alexander Gerard) miałem już okazję zaprezentować czytelnikowi między innymi w: Smak, geniusz, sztuka. Filozofia piękna Alexandra Gerarda w świetle estetyki kantowskiej (Toruń: WN UMK, 2009); Wyobraźnia i wzniosłość. Teoriopoznawcze podstawy wybranych brytyjskich koncepcji estetycznych XVIII wieku (Toruń: TAKO, 2010); „Alexander Gerard's Correction of Hume's Standard of Taste”, Вісник НАУ. Серія: Філософія. Культурологія, Збірник наукових праць, Київ (2016): 6-11, a także „Dobre towarzystwo - rozwój smaku estetycznego w dobie Oświecenia", w: Znaczenie filozofii Oświecenia. Człowiek wśród ludzi, red. Barbara Grabowska, Adam Grzeliński, Jolanta Żelazna (Toruń: WN UMK, 2016). Opracowanie pokrewnych zagadnień w polskiej literaturze przedmiotowej, dotyczących w szczególności estetyki brytyjskiej, znajdzie czytelnik między innymi w: Adam Grzeliński, Angielski spór o istotę piękna. Koncepcje estetyczne Shaftesbury'ego i Burke'a (Toruń: Wydawnictwo 
się na tym, co stanowiło w tamtym okresie wspólny mianownik głoszonych teorii estetycznych, którym był cel przyświecający ich powstaniu: określenie tego, czym jest smak i doświadczenie estetyczne. Z powodu takiego właśnie przedmiotu zainteresowania całą epokę określano mianem wieku smaku, a teorie estetyczne - estetyką smaku².

Skupienie się na tej problematyce należy wiązać z kilkoma czynnikami. Przede wszystkim z kryzysem wielkiej teorii piękna opartej na klasycznej sztuce, skoncentrowanej głównie na formie, proporcji i układzie części. Wspomniana teoria nie potrafiła sprostać wynikom filozofii empirycznej, analiz psychologicznych czy krytyce literatów i artystów. Przyczynili się do tego również wielcy myśliciele ubiegłego stulecia, a mianowicie René Descartes, Baruch Spinoza czy Thomas Hobbes, dla których piękno miało charakter jedynie subiektywny. W związku z powyższym piękno niespecjalnie interesowało ich jako przedmiot badań ${ }^{3}$. Przeciwko pięknu rozumianemu w sposób obiektywny, jak się uważało, przeczyło codzienne doświadczenie, które w dobie triumfów myśli Johna Locke'a czy później Davida Hume’a rozkładano na czynniki pierwsze i doszukiwano się w nim psychologicznych ludzkich reakcji na postrzegane piękno. Wyodrębnienie z niego kolejnych kategorii estetycznych, takich jak wzniosłość czy malowniczość, przypieczętowało los liczącej ponad dwa tysiące lat teorii.

Zainteresowanie smakiem wiąże się jednak również ze zjawiskiem demokratyzacji sztuki oraz ze wzrostem skupienia uwagi odbiorców na piśmiennictwie: literaturze oraz coraz bardziej popularnych pismach pokroju Spectatora, redagowanego przez Josepha Addisona (1672-1719)

Adam Marszałek, 2001); Marta Śliwa, Teoria piękna w filozofii Francisa Hutchesona (Olsztyn: UWM, 2009); Stefan Morawski, „O podstawowych zagadnieniach estetyki angielskiej XVIII w.", w: Studia z historii myśli estetycznej XVIII i XIX w. (Warszawa: 1961), jak również w fundamentalnej dla tej materii pracy: Stanisław Pazura, De gustibus. Rozważania nad dziejami pojęcia smaku estetycznego (Warszawa: PWN, 1981). W literaturze anglojęzycznej po dziś dzień prym wiodą monumentalne dla tego przedmiotu dociekań prace: Walter Hipple, The Beautiful, the Sublime, and the Picturesque in Eighteenth-Century British Aesthetic Theory (Carbondale: The Southern Illinois University Press 1957); Samuel Monk, The Sublime: A Study of Critical Theories in XVIII-Century England (Ann Arbor: University of Michigan Press, 1960); Peter Kivy, The Seventh Sense. A Study of Francis Hutcheson's Aesthetics And Its Influence in Eighteenth-Century Britain (New York: Burt Franklin \& Co., 1976).

2 Określenie „estetyka smaku” ukute przez Franza Schümmera przyjmuje choćby Stanisław Pazura w przywołanej wcześniej pracy, George Dickie zaś wykorzystuje pierwsze z nich między innymi w tytule swej najważniejszej książki poświęconej tej tematyce, zob. George Dickie, The Century of Taste. The Philosophical Odyssey of Taste in the Eighteenth Century (New York: Oxford University Press, 1996).

3 Warto by w osobnej pracy zastanowić się nad tym, czy René Descartes nie podzieliłby poglądu Addisona na piękno dowodu matematycznego, które wynika przede wszystkim z rozumowego zachwytu nad jego ładem czy prostotą. 
i Richarda Steela (1672-1729), podejmujących szeroko rozumianą problematykę społeczną i popularyzatorska, a przy tym mających, jakże często, charakter moralizatorski. Nie bez znaczenia dla obserwowanych zmian pozostaje rozwój krytyki literackiej. Trudno też nie dostrzec, że wzrost popularności najrozmaitszych dzieł apelujących do wyobraźni aktywnych uczestników życia społecznego był uwarunkowany awansem kulturowym mieszczaństwa i potrzebą realizowania się i uczestniczenia $\mathrm{w}$ życiu towarzyskim. Angielski odpowiednik francuskich salonów stanowiły wszechobecne na Wyspach kawiarnie. Smak, tym samym, okazał się nie tylko odgrywać decydującą rolę w sferze estetycznej, ale i stanowić podstawę dobrych obyczajów, współgrać z ogłada, polorem, a nawet spełniać rolę busoli moralnej.

Spierano się jednak o istotę smaku. Określanie go na wzór piękna, jako je ne sais qoui, nikogo już wówczas nie zadowalało. Najważniejsze pytanie dotyczyło tego, czy smak jest zdolnością autonomiczna, czy do swego prawidłowego funkcjonowania potrzebuje innych władz czy zdolności ludzkich, a jeśli tak, to jakich. Shaftesbury (właśc. Anthony Ashley-Cooper, III Lord Shaftesbury: 1671-1713), Francis Hutcheson (1694-1746), a nawet w pewnym zakresie David Hume (1711-1776), postulują istnienie zmysłu wewnętrznego czy moralnego, rozumiejąc przez to bądź to intuicyjną zdolność oceny formy przedmiotów i działań ludzkich, bądź rodzaj uczucia, czy właściwie poczucia, na przykład piękna, w przedmiotach i czynach. Ale Hume przyjmuje również, że smak jest ufundowany na wyobraźni i bez niej, tak jak i bez poprawnie działających zmysłów, właściwie nie mógłby funkcjonować. Edmund Burke (1729-1797), który we Wstępie drugiego wydania swych Dociekań filozoficznych o pochodzeniu naszych idei wzniosłości i piękna najwyraźniej z nim polemizuje, twierdzi, że smak nie jest żadną odrębną władza, a składają się na niego zmysły, wyobraźnia i sąd (judgment). Będzie to dla niego podstawa do rozróżnienia smaku naturalnego, opierającego się na zmysłach i wyobraźni, oraz smaku krytycznego, wspartego na wiedzy i rozumie ${ }^{5}$. Podobny podział, jak zobaczymy, znajdzie się również w koncepcji estetycznej Gerarda. Oznacza to, że palącym wówczas problemem w odniesieniu do smaku było określenie stosunku tego, co irracjonalne i racjonalne, tego, co ma charakter uczuciowy, subiektywny, do tego, co po stronie przedmiotowej doświadczenia estetycznego daje się ująć w określone reguły, prawa, tj. tego, co obiektywne. W tle pozo-

${ }^{4} \mathrm{Na}$ temat rozwoju ówczesnego piśmiennictwa, krytyki literackiej, zjawiska towarzyskości czy wreszcie funkcjonowania salonów w Londynie zob. Kazimierz Maliszewski, Stolica świata. Studia z dziejów życia kulturalnego i umysłowego Londynu w XVIII wieku (Warszawa: Wydawnictwo DiG, 2014).

${ }^{5}$ Edmund Burke, Dociekania filozoficzne o pochodzeniu naszych idei wzniosłości i piękna, przeł. Piotr Graff (Warszawa: PWN, 1968), 22. 
stawały pytania o możliwość kształcenia smaku i kryteria poprawności jego sądów.

Tendencja epoki do ujmowania piękna jako subiektywnego wrażenia sprawiła, że główny przedmiot analiz, tj. smak, przejęty od Francuzów wiążących go przede wszystkim z ogólnymi ideałami kultury salonowo-dworskiej, jakże dalekimi od wyobrażenia na temat smaku pociesznych wykwintniś Moliera z początku XVII wieku, zmienia się w smak rozpatrywany jako podmiotowa reakcja ${ }^{6}$. Reakcja, której istoty starano się dociec, a jej charakter określano niemal zawsze jako pewną mieszaninę elementów zmysłowo-emocjonalnych i racjonalnych. Klasycystyczne ujęcie piękna, w przypadku którego rozum odgrywał jeszcze tak ważną rolę, słabnie i stopniowo przemija, by ostatecznie czynnik irracjonalny obecny w doświadczeniu estetycznym wziął nad nim górę. I choć Shaftesbury na początku stulecia postulował istnienie obiektywnie pojmowanego piękna na wzór platońskiej idei, a Hutcheson głosił jedynie, że nie każde piękno ma obiektywny charakter, to w tym samym czasie Addison sprowadził je do swoistych przyjemności wyobraźni, powiązanych z tajemniczą satysfakcja, radością i zadowoleniem ${ }^{7}$.

Mniej więcej od połowy stulecia pogląd subiektywistyczny zaczyna dominować w brytyjskich rozważaniach nad szeroko pojmowanymi zjawiskami estetycznymi. Burke przeczy, by piękno miało cokolwiek wspólnego z proporcja symetrią czy użytecznością. Hume sprowadza je do przeżycia: „Piękno nie jest właściwością przedmiotów samych przez się - czytamy w Sprawdzianie smaku - istnieje jedynie w umyśle, który je ogląda, a każdy umysł dostrzega inne piękno"s. Pomimo tego obaj byli dalecy od relatywizmu i każdy z nich na swój sposób wprowadzał element ratio do swej koncepcji. Pierwszy przyjmował, że od wiedzy zależy doskonalszy smak, a przy tym, że rozumu radzimy się wówczas, gdy oceniamy decorum dzieł sztuki lub kwestie moralne w nich unaocznione. Drugi natomiast, któremu nawet w Traktacie zdarzało się sprowadzać piękno do proporcji, symetrii czy nawet użyteczności, w esejach próbuje dorzucić nikłe światełko rozumu w postaci zaproponowanej konstrukcji, jaką miał być sprawdzian smaku: ów zgodny sąd sprawiedliwych krytyków, wspierany przekonaniem, że piękne jest to, co zawsze i wszędzie wszystkim się podoba, to, co już u swego pierwszego znanego nam twórcy, rzymskiego retora z I wieku naszej ery, Pseudo-Longinosa - jak

6 Proces ten dość szczegółowo omawia Pazura, zob. Pazura, De gustibus, 19-42.

$7 \mathrm{Na}$ temat początków osiemnastowiecznej refleksji estetycznej na Wyspach Brytyjskich zob. Wawrzonkowski, Wyobraźnia $i$ wzniosłość, zwłaszcza rozdz. II.1. Entuzjazm i wzniosłe piękno. Shaftesbury, oraz rozdz. II.2. Początek oddzielenia piękna i wzniostości. Joseph Addison.

8 David Hume, „Sprawdzian smaku”, w: David Hume, Eseje z dziedziny moralności i literatury, przeł. Teresa Tatarkiewiczowa (Warszawa: PWN, 1955), 194. 
przyjęło się go nazywać - miało wzajemnie znosić indywidualne upodobania9.

Koniec XVIII wieku przynosi koncepcję Archibalda Alisona (1757-1839), któremu jako pierwszemu udaje się w pełni wykorzystać wskazane przez Hume'a, a po raz pierwszy użyte do wyjaśnienia natury snów przez Arystotelesa, związki kojarzeniowe wyobraźni. W ten sposób spór z rozumem o naturę smaku i wiodącą $\mathrm{w}$ nim prym władzę, wygrywa właśnie wyobraźnia. $\mathrm{W}$ takim też stanie zaawansowania badań Brytyjczycy pozostawiają estetykę Niemcom. Krytyka władzy sądzenia Immanuela Kanta niejako konsumuje blisko stuletnie rozważania prowadzone na Wyspach. Zrywa z dominującym tam psychologizmem, a smak ujmuje jako refleksywną władzę sądzenia i opiera go na wolnej grze władz poznawczych. Kończy się wiek smaku, a zaczyna okres panowania geniuszu.

Alexander Gerard był szkockim filozofem, teologiem i estetykiem. Jednym z członków Towarzystwa Filozoficznego w Aberdeen, postacią silnie oddziałującą na swoje środowisko i życie umysłowe "doskonalącego się" wówczas społeczeństwa szkockiego. W jego poglądach przebijają się myśli reformatorskie. Są one rozproszone zarówno w pomniejszych pismach o charakterze duszpastersko-wychowawczym, teologicznym i retorycznym, jak i obszernych pracach o charakterze stricte estetycznym, w Eseju o smaku z 1756 roku i monumentalnym Eseju o geniuszu z 1774 roku. Wyłania się z nich obraz nauki, która - by móc sprzyjać ludziom, ich potrzebom praktycznym, pełnieniu ważnych społecznie funkcji, kształceniu krytycznego namysłu nad otaczającą ich rzeczywistością, stałemu udoskonalaniu smaku czy rozwijaniu ich kreatywności - musi się zmienić. Owa zmiana miałaby polegać na położeniu większego nacisku w trakcie odbywanych studiów na przyswajanie wiedzy z zakresu logiki, epistemologii czy filozofii moralnej i retoryki ${ }^{10}$. Jednocześnie Gerard przyjmuje ideały wyrażone ponad sto lat wcześniej przez Francisa Bacona, którego metodologiczny nacisk na rolę doświadczenia zmysłowego, eksperymentu i indukcji w nauce zdawał się umożliwiać

9 W tamtym czasie Peri hypsous był za sprawą przekładu i dołączonego obszernego wprowadzenia Nicolai Boileau faktycznie bardzo popularny, a przez wyraźne opowiedzenie się Longinosa w sporze o istotę twórczości po stronie Platona i podkreślenie przezeń roli entuzjazmu w powstawaniu dzieł, a przeciw definicji tragedii Arystotelesa i związanego z jego estetyką szkolarstwa i ścisłego przestrzegania reguł, został całkiem dobrze przyjęty. Wątki irracjonalne świetnie odpowiadały duchowi epoki.

${ }^{10}$ Charakterystykę reform proponowanych i przeprowadzanych przez Gerarda opisuje Stefan Zabieglik (zob. tenże, „Wiek doskonalenia. Z filozofii szkockiego oświecenia", Zeszyty naukowe Politechniki Gdańskiej, Filozofia III, 558 (1997): 52), postać zaś Gerarda i jego działalność naukową - Marta Śliwa (w: taż, „Philosophical Societies in the Scottish Enlightenment”, Ruch Filozoficzny LXXIV, 3 (2018): 107-117. 
mu dalszy jej rozwój i osiągnięcie na tej drodze postępu ludzkości. Scholastyczną metodę kształcenia podważał w duchu krytyki wymierzonej $\mathrm{w}$ nią przez Isaaca Newtona. $\mathrm{W}$ jego pracach, zwłaszcza $\mathrm{z}$ dziedziny estetyki, widać, jak duży nacisk położony jest na rolę ratio, zarówno w zwykłym doświadczeniu, jak i specyficznej jego odmianie, którą jest doświadczenie estetyczne. Przypisanie tak ważnej roli rozumowi było wówczas na Wyspach zjawiskiem bardzo rzadkim, niemającym właściwie, w takim wymiarze i tak różnych zakresach, odpowiednika w żadnej z tamtejszych koncepcji estetycznych.

Zdaniem Gerarda smak nie jest w całości ani darem natury, ani działaniem sztuki. Zasadza się na naturalnych ludzkich zdolnościach umysłu, które należy odpowiednio kształcić, by osiągnęły właściwą sobie doskonałość. Przez owe zdolności filozof rozumie zmysły wewnętrzne czy też refleksyjne. Zaprzecza jednak, by można było sprowadzić je do jakichkolwiek organów zmysłów i przyznaje zarazem, że nazywa je tak jedynie w sposób metaforyczny. Jest świadomy tradycji, z której ten termin się wywodzi. Sam wykorzystuje go tylko dlatego, że chce zwrócić uwagę na natychmiastowość doświadczenia estetycznego, na fakt, że chodzi o ujmowanie pewnych treści. Nie rozkłada ich jednak na poszczególne postrzeżenia czy elementarne dane zmysłowe. Zmysły wewnętrzne $\mathrm{w}$ jego ujęciu odnoszą się bowiem do całych agregatów jakości, do całych układów kompozycji, do scen pełnych skojarzeń i przedstawień wkomponowanych w najróżniejsze konteksty. Zalicza do nich zmysł: piękna, wzniosłości, nowości, naśladownictwa, harmonii, śmieszności i cnoty. Każdy z nich ujmuje właściwe sobie zjawisko, ale i wspiera pozostałe $\mathrm{w}$ ich własnej pracy. To dzięki ich zestrojeniu, pewnemu szczęśliwemu zjednoczeniu, powstaje wyjątkowy smak, niepowtarzalny, o określonym przez dominanta charakterze i określonej wrażliwości ${ }^{11}$. Czym zatem są owe zmysły wewnętrzne?

Wydaje się, że Gerard, w większym stopniu niż współcześni mu teoretycy smaku, próbuje zdać sprawę z dostrzegalnej różnorodności

11 Zob. następującą uwagę filozofa: „Nasze sentymenty i wzruszenia niezmiernie zyskują na intensywności dzięki wzajemnemu na siebie oddziaływaniu. Spowinowacone ze sobą wzruszenia, powiązane uczuciem, kierunkiem lub przedmiotem, które je wywołały, a nawet niezaistniałe w umyśle w żadnym pokrewieństwie, zlewają się w jedno odczucie i przez to połączenie wywołują mocną impresję. Stąd właśnie biorą się różnorakie przyjemności, mające swe źródło w jednym lub w wielu zmysłach; nasuwają się one jednocześnie umysłowi, sprawiając mu złożoną satysfakcję" (Alexander Gerard, „Esej o guście”, fragmenty, przeł. Zofia Sinko, w: Europejskie źródła myśli estetyczno-literackiej polskiego oświecenia. Antologia wypowiedzi pisarzy francuskiego, niemieckiego i angielskiego obszaru językowego. 1674-1810, red. Teresa Kostkiewiczowa i Zbigniew Goliński (Warszawa: Semper, 1997), 627. Dla tak kumulujących się przeżyć nie bez znaczenia pozostaje fakt, który ze zmysłów wewnętrznych pozostaje najlepiej rozwinięty, daje najwyższy rodzaj satysfakcji i emocjonalnie zabarwia całość estetycznego doświadczenia. 
jego sądów, przyjąć ją z całym dobrodziejstwem, wyjaśnić i ufundować na ludzkich zdolnościach. Smak jest pochodną wyobraźni, owe zmysły czy smaki szczegółowe są więc jej zdolnościami. Powiedziałbym nawet: zasadami czy kryteriami, według których określone przedmioty poruszają wraz z wyobraźnią cały umysł, przepełniają go radością zadowoleniem, poczuciem dumy, spełnienia, własnej wartości i możliwości. Każdy przedmiot smaku czyni to na swój sposób. Każdego porusza inaczej z powodu odmiennego zestrojenia zmysłów, a przecież wszystkich w tym samych granicach, ze względu na właściwy dla każdego z nich odmienny sposób działania.

Powstałe uczucia i poruszenia kumulują się. Poszczególne zmysły wspierają się wzajemnie i uzupełniają, wpływając na wiodący stan czy dyspozycję umysłu, podtrzymują ją. Jak czytamy w Eseju o smaku:

Każdy ze zmysłów wewnętrznych, jeżeli tylko działa silnie i bezbłędnie, tworzy szczególny rodzaj gustu i umożliwia człowiekowi wydawanie sądu w jakiejś materii związanej ze sztuką lub geniuszem. Jednakże wszystkie wspomniane zmysły muszą być czynne równocześnie, a to w celu kształtowania smaku o właściwym mu zasięgu. Związek ten jest nieodzowny nie tylko dla wyznaczenia gustowi stosownego zakresu, ale także dla wydoskonalenia każdego przejawu smaku' ${ }^{12}$.

Zdaniem Gerarda poszczególne zmysły potrafią nawet bilansować mniej wartościowe doznania płynące z pozostałych, powetować niejako straty płynące z obcowania $\mathrm{z}$ dziełem mającym pewnie niedostatki. Możliwości wzajemnego oddziaływania, obierania wspólnego kursu i potęgowania siły wzruszeń są niezliczone.

$\mathrm{Na}$ takiej charakterystyce smaku moglibyśmy właściwie poprzestać, gdybyśmy chcieli rozpatrywać smak tylko jako wrażenie, jako ocenę elementarną czy też smak naturalny, jak chciałby przykładowo Burke; gdybyśmy tylko ową naturalność zdołali pogodzić z całą konstelacją związków kojarzeniowych wyobraźni, których mechanizmy dla Gerarda stanowią jedno z wyjaśnień udzielania się nam najrozmaitszych uczuć. Burke nie uznawał asocjacji za naturalne, a co najwyżej za sztuczne powiązanie. $Z$ całą pewnością odrzucał możliwość wyjaśnienia poprzez nie istoty piękna czy wzniosłości. Mogły za to prowadzić do wypaczenia smaku. Pamiętajmy, że dla Locke'a, którego teoriopoznawcze rozważania $\mathrm{w}$ znacznym stopniu stanowiły filozoficzną podbudowę koncepcji estetycznej Burke’a, takie związki oznaczały niewłaściwe powiązanie między przedmiotami myśli i mogły świadczyć o pewnej

12 Alexander Gerard, An Essay on Taste to which is now added part fourth, Of the Standard of Taste, $3^{\text {rd }}$ ed. (London-Edinburgh: J. Bell and W. Creech and T. Cadell, 1780), 148. 
ułomności umysłu ich twórcy ${ }^{13}$. Ale Gerard inaczej zapatruje się na istotę smaku. By odróżnić go od tak zarysowanego smaku naturalnego i móc określić go jako refleksyjny, filozof wprowadza na scenę rozum. Początkowo czyni to dość ostrożnie.

W pierwszej kolejności rozważa swoistą ludzką dyspozycję, jaką jest czułość serca. Stwierdza, że usposabia ona człowieka do łatwego wzruszania się i poddawania uczuciom, że umożliwia ocenę zarówno dzieł sztuki, jak i przedmiotów przyrody na podstawie niemal wyłącznie uczuć $^{14}$. Zauważa jednak, że sądy smaku estetycznego zdarza się ferować i tym, którzy owej wrażliwości są pozbawieni. Ich serca mają bardziej zatwardziały charakter, brak im empatii i nie znają uczucia litości. Bliższy jest im sąd (rozumowy), a z braku wrażliwości nie mogą - jak sugeruje Gerard - zasmakować w tym, co przemawia do serca. Zdarza im się wiedzieć, jaka jest wartość dzieła, kogo ono poruszy i z jakich powodów. Świetnie zdają sobie sprawę z jego kompozycji, zalet i wad, ale bez delikatności uczucia, powiązanej z żywością poszczególnych zmysłów wewnętrznych, ich smak nigdy nie zyska pełnego zakresu. Choć sąd takiego smaku wybrzmi tak samo jak uczuciowa reakcja, na innej będzie się opierał podstawie. Dlatego tak ważne jest wsparcie smaku przez sąd, przez rozum. $Z$ tego właśnie powodu ten ostatni bezwzględnie musi mu towarzyszyć:

Zmysły muszą zyskać poparcie sądu (judgment) - władzy umysłu, która
wprowadza rozróżnienie między rzeczami, oddziela prawdę od kłam-
stwa oraz porównuje ze sobą przedmioty oraz ich cechy. Sąd musi to-
warzyszyć nawet najbardziej niedoskonałym działaniom zmysłów. Nie
działają one bowiem, dopóki pewne cechy przedmiotów nie zostały po-
strzeżone, odróżnione od innych im podobnych, porównane i złożone

${ }^{13}$ W dodanym do czwartego wydania Rozważań dotyczących rozumu ludzkiego z 1700 roku rozdziale, zatytułowanym O kojarzeniu idei, powiązanie między nimi powstałe na drodze skojarzenia Locke traktuje jako objaw obłędu czy wręcz szaleństwa, zob. John Locke, Rozważania dotyczące rozumu ludzkiego, przeł. Bolesław Józef Gawecki (Kraków: PWN, 1955), 562 i n.

${ }^{14}$ Por. następującą uwagę Gerarda na temat dyspozycji, jaką jest czułość serca, „która usposabia człowieka do łatwego wzruszania się i do gotowości poddania się niczym chorobie - każdemu uczuciu, jakie zdolne jest w nim wzniecić dzieło sztuki. Dusze ludzkie zgoła nie są podobnie wrażliwe na impresje tego rodzaju. Człowiek o twardym sercu może być świadkiem ciężkiej niedoli bez doznawania żadnego wzruszenia. Człowiek o okrutnym charakterze czerpie złośliwą radość z zadawania cierpienia. Z drugiej strony wielu ukształtowanych jest $\mathrm{z}$ tak delikatnych materii, iż najlżejsze zmartwienie bliźnich wzbudza ich litość. Najbardziej wstrząsająca tragedia niewiele poruszy osobę twardego serca, ci o tkliwym usposobieniu odczuwają zaś strapienie spowodowane błahym przypadkiem. [...] Różnorodność w uformowaniu serca ludzkiego przywodzi do znacznej różnorodności sentymentów, jakie ludzie czerpią z dzieł gustu, a także do rozmaitych sądów, jakie o nich podejmują" (Gerard, Esej, 630). 
pospołu. Sąd zajmuje się tym wszystkim; bierze udział w rozróżnianiu i wystawianiu podobizny każdego przedmiotu, który podpada pod zmysły. Wspierając wszakże ich doskonałe i żywe działania, posiada jeszcze znaczniejszy wpływ. Trafne rozeznanie jest niezastąpionym składnikiem dobrego smaku, ponieważ zawsze wiedzie do natychmiastowego i dokładnego postrzeżenia w ich rzeczywistej postaci. Tego rodzaju sąd może w pełni wystawić zmysłom wewnętrznym piękno i niezwykłe powaby natury; mierzy on rozległość przedmiotów, ustala ich proporcje, śledzi ich celową budowę i zbawienne pożytki. Używa wszelkich sposobów, jakie podsuwają mu sztuka i nauka, a to dla odkrycia tych przymiotów, które spoczywają zbyt głęboko, aby natychmiast rzucić się w oczy. Sąd docieka praw i przyczyn w dziełach natury, porównuje je i przeciwstawia mniej doskonałym dziełom sztuki, w ten sposób dostarcza materiałów: a z nich wyobraźnia może tworzyć idee i kształtować różnorakie formy, które wywrą silne piętno na smaku wspartym skłonnością umysłu ${ }^{15}$.

Ten długi cytat doskonale oddaje rolę, jaką zdaniem Gerarda rozum i jego sąd pełnią zarówno w zwykłym doświadczeniu zmysłowym, jak i w doświadczeniu estetycznym. To rozum wystawia zmysłom właściwy przedmiot, ale także porównuje i rozważa ich oceny. To on feruje ostateczny werdykt. Precyzja sądu nie zastąpi wrażliwości zmysłów wewnętrznych czy wyobraźni, ale wespół osiągają doskonałość. Taki smak, nazywany porównawczym czy refleksyjnym, nie tylko daje się kształcić, ale i można dla niego wskazać swoiste kryterium poprawności, poszukiwany przez Hume'a sprawdzian smaku. Nie jest on jednak zgodnym sądem sprawiedliwych krytyków na temat dzieł sztuki. Gerard odrzuca takie rozwiązanie.

Będąc najprawdopodobniej inspiracją dla Hume'owskich rozważań estetycznych, Esej o smaku Gerarda doczekał się trzech wydań. W ostatnim z nich, z roku 1780, pojawił się dodatkowy, dość obszerny rozdział zatytułowany właśnie Sprawdzian smaku. Punkt po punkcie Gerard rozprawia się w nim z propozycją autora Traktatu..., a w jej miejsce proponuje własne rozwiązanie: $\mathrm{w}$ duchu naukowym, oparte na indukcji, zgromadzeniu olbrzymiej ilości materiałów porównawczych, utworzeniu katalogów jakości zmysłowych i ludzkich na nie reakcji. Wszystko w oparciu o znajomość ludzkiej natury. Wszystko dokonane przez sprawiedliwych krytyków, bacznych obserwatorów człowieka, jego tworów, dzieł sztuki, tego, co go otacza, przedmiotów przyrody, zjawisk atmosferycznych, rozpościerających się widoków i ludzkiego umysłu, z mechanizmami, które rządzą zmysłami, wyobraźnią, rozumem:

Krytyk jest tym - czytamy - który nie tylko czuje mocniej, ale również jest zdolny do namysłu nad swymi uczuciami, wyjaśnienia ich, rozróżnienia

15 Gerard, Esej, 631. 
ich przedmiotów i wyśledzenia ich przyczyn. Z tego powodu posiada on naturalne predyspozycje do objęcia przywództwa w formowaniu [sądów] dotyczących dzieł smaku. To właśnie zbieżność [sądów] osób o takim charakterze oświeca i ukierunkowuje sądy większości. Powszechna aprobata ma swe źródło zarówno w dyskusji, jak i w uczuciach. Oczywiste jest, że krytyk ma prawo badać przyczyny naszych przyjemności i przykrości, lecz jeśli te badania przyczynią się do większej precyzji i pewności naszych sądów, będzie to wynikało z tego, że dostarczą nam one dokładniejszego sprawdzianu niż zwykłe uczucia. Zaprzecza się, jakoby miał on jakiekolwiek prawo do orzekania, że nie jest dobre to, co rzeczywiście przyjemne, lub że nie jest złe to, co rzeczywiście przykre. Nie może on mieć prawa zaprzeczania powszechnie panującym odczuciom i określać, że coś jest przyjemne bądź nie i prawdziwy krytyk nigdy tego nie czyni. Ale zaprzeczać, że ma on prawo do orzekania, że nie jest dobre to, co rzeczywiście budzi u niektórych przyjemność, i że nie jest złe to, co rzeczywiście sprawia niektórym przykrość, oznaczałoby przyznanie, że każdy smak posiada swój własny niezaprzeczalny autorytet. Krytyk ma prawo rozróżniać to, co naturalne, i to, co przypadkowe, krzepkie i liche i to on właśnie może dokonywać tych rozróżnień w najbardziej satysfakcjonujący sposób, przy czym mogą one być uzasadnione tylko dzięki ogólnym regułom, które poddaje on badaniu' ${ }^{16}$.

Raz jeszcze zatem widzimy, jak w kolejnym aspekcie funkcjonowania smaku, a mówiąc dokładniej - przy próbie odkrycia swoistego dla sądów smaku probierza poprawności, rozum odgrywa wiodącą rolę. Poszukiwany przez wielu sprawdzian smaku nie kryje się w powszechnej aprobacie ${ }^{17}$, nie wynika z uzgodnienia czy przypadkowego konsensu, ale zostaje wyprowadzony przez krytyków na drodze rozumowych wniosków z empirycznych badań nad człowiekiem i jego światem. Ludzka natura okazuje się ostatecznym źródłem sprawdzianu. Mimo całej różnorodności doświadczeń i wrażliwości każdego człowieka pozostaje ona scena, na której oglądamy najrozmaitsze przejawy niezmiennych mechanizmów wyobraźni i zasad smaku, reguł umysłu, przy pomocy których krytyk wysnuwa wnioski. Nie może więc też dziwić, że rola rozumu nie powinna ograniczać się tylko do wybranych aktywności człowieka. Tak jak bowiem ludzka natura daje o sobie znać w działaniach smaku, tak też musi dać się ją dostrzec na innych polach aktywności człowieka, w tym w twórczości artystycznej. A jeśli chcemy skupić się na jej najdonioślejszych dziełach, musimy zwrócić się do nietuzinkowego ich twórcy, do geniusza.

Koncepcja geniuszu i twórczości zaproponowana przez Gerarda już w swej pierwszej odsłonie na łamach Eseju o smaku zakładała znaczny

16 Gerard, An Essay on Taste, 244.

17 Ta może być z nim w zgodzie lub z niego wynikać, ale sama nie może stanowić podstawy do wyprowadzania wniosków natury ogólnej w tej kwestii. 
udział rozumu i sądu ${ }^{18}$. I choć podstawową cechą geniuszu czy genialności jest dla niego „inwencja, która polega na szerokim zasięgu i pojemności wyobraźni, gotowej kojarzyć ze sobą najodleglejsze idee, pozostające wszakże $\mathrm{w}$ jakimś powinowactwie" ${ }^{19}$, dyspozycje kojarzenia geniuszu są zaś w jego ujęciu ,tak silne i działają tak raptownie, iż kiedykolwiek rodzi się w jego umyśle jakaś idea, natychmiast pojawiają się inne, mające z ideą główną jakiś luźny związek" ${ }^{20}$, to jednak tej wyjątkowej ludzkiej zdolności nie da się sprowadzić jedynie do działania wyobraźni i funkcjonowania jej związków kojarzeniowych. Prawdą jest, że zmysły wewnętrzne są względem wyobraźni pochodne, tak samo jak smak czy geniusz, i że to wraz z dominującym sposobem kojarzenia idei odpowiadają one za różnorodność w obrębie twórczości, za oryginalne unaocznianie głównej idei dzieła i zrealizowanie go w najdrobniejszych szczegółach. Ale geniusz, któremu smak podcina skrzydła czy też dla którego, niczym u Kanta, smak stanowi wędzidło, nie może obejść się bez wsparcia ze strony sądu:

Regularność działania wyobraźni - powiada Gerard - która ma tak olbrzymie znaczenie dla geniuszu, nigdy nie może być osiagnięta bez wsparcia ze strony sądu. Tylko dzięki temu, że sąd stale z nią współpracuje, często sprawdzając i poddając badaniu jej idee, stopniowo powstaje pewien nawyk dokładnego myślenia, zapewniając, że umysł podąża prosto ku wytkniętemu celowi, nie zbaczając na poboczne ścieżki. Wyobraźnia jest władzą tak ze swej natury dziką że dopiero poprzez nawyknienie do dyscypliny rozumu staje się wystarczająco oswojona, aby w odpowiedni sposób tworzyć. Nawet jeśli działania wyobraźni osiagną największą możliwą regularność, dopóki nie będzie towarzyszył jej sąd nieustannie korygujący jej aktywność, dopóty nie będzie ona zdolna do takiej twórczości. Najbardziej nawet regularnie funkcjonująca wyobraźnia niekiedy zbacza z właściwej drogi i przedstawia nieodpowiednie idee; sąd musi być wówczas gotów do oceny jej pracy i odrzucenia takich idei ${ }^{21}$.

${ }^{18} \mathrm{~W}$ tym miejscu warto wspomnieć, że koncepcji geniuszu zaproponowanej przez Szkota nie towarzyszyła przez blisko sto lat żadna równie imponująca teoria mogąca poszczycić się wykorzystaniem najnowszych osiągnięć - co prawda wciąż raczkującej jeszcze - psychologii i że pozostawała ona jedną z najważniejszych ówczesnych prac poświęconych szeroko pojmowanej twórczości, rozpatrywanej na gruncie zarówno nauki, jak i sztuki. Na ten temat zob. Meyer Howard Abrams, Zwierciadto i lampa. Romantyczna teoria poezji a tradycja krytycznoliteracka, przeł. Maria Bożenna Fedewicz (Gdańsk: słowo/obraz terytoria, 2003), 174. W kwestii wpływu koncepcji geniuszu na rozważania Kanta zob. Krzysztof Wawrzonkowski, „O podobieństwach między koncepcjami geniuszu Gerarda i Kanta", w: Aktualność estetyki Kanta, red. Kinga Kaśkiewicz, Piotr Schollenberger (Toruń: WN UMK, 2015), 31-48.

${ }_{19}$ Gerard, Esej, 633.

20 Tamże.

${ }^{21}$ Alexander Gerard, An Essay on Genius (London-Edinburgh: W. Strahan; T. Cadell, 1774), 81. 
Ponownie widzimy zatem propozycję, by pracę wyobraźni, stanowiącej źródło dla smaku i geniuszu, poddać korekturze ze strony rozumu, by jej idee zweryfikować ostatecznie przez sąd, a tym samym obie zdolności wesprzeć i udoskonalić we właściwych im działaniach. I choć w przypadku smaku i geniuszu wyobraźnia w odmienny sposób objawia swe funkcjonowanie, przyczyniając się bądź do oceny, bądź do tworzenia ${ }^{22}$, to rozum $\mathrm{w}$ równym stopniu winien brać w nim udział, każdorazowo odgrywając rolę w uzyskaniu przez nie właściwego im zakresu działania i osiągnięcia pełni możliwości.

Roli rozumu w teorii estetycznej Gerarda nie sposób zatem nie docenić $^{23}$. Stanowi on o różnicy między smakiem, rozumianym jako wrażenie, jako indywidualnie zabarwione emocjonalne doznanie pewnych jakości ujmowanych na drodze zmysłowej, a smakiem kształconym, uwzględniającym nie tyle tylko materiał porównawczy wcześniej zdobyty, ale i określony, i w pełni wystawiony umysłowi poprzez najróżniejsze rozumowe kryteria, które niczym siatka pojęć stanowią dla niego konstrukcję, dzięki której to, co postrzegalne, może zostać również osądzone. Ratio sądzi. Nie obejdziemy się zatem bez niego i przy twórczości, która nie jest operacją mechaniczna, zasadzającą się na prostym składaniu dostarczonych przez zmysły materiałów, ale takim ich oryginalnym przepracowaniu, że ich ostateczne opracowanie staje się wyrazem nieszablonowego myślenia i kształconej wyobraźni, wzorem dla kolejnych pokoleń, stanowiącym zaprzeczenie naśladownictwa, mniej lub bardziej świadomym wyborem powiązań między ideami, dokonanym z całej gamy możliwych rozwiązań.

\section{Bibliografia}

Abrams Meyer Howard. 2003. Zwierciadło i lampa. Romantyczna teoria poezji a tradycja krytycznoliteracka, przeł. Maria Bożenna Fedewicz. Gdańsk: słowo/obraz terytoria.

${ }^{22} \mathrm{~W}$ tym też tkwi istotna rola smaku względem geniuszu, której należy doszukiwać się w ograniczaniu jego oryginalnych zapędów.

${ }^{23}$ Tym bardziej, że na gruncie osiemnastowiecznej estetyki brytyjskiej nikt inny nie zajmie tak jasno określonego stanowiska w kwestii roli rozumu w doświadczeniu estetycznym i nikt nie przypisze mu jej w tak wielkim zakresie co Gerard. Tym niemniej rozum - w różnych przejawach jego funkcjonowania - znajdzie miejsce w koncepcjach takich późniejszych estetyków, jak choćby: James Beattie (1753-1805), Archibal Alison, Douglas Stewart (1753-1828) czy Hugh Blair (1718- 800). Bez wątpienia jednak to Burke, a później Gerard dokonali przełomu na Wyspach i dzięki wprowadzeniu do opisu doświadczenia estetycznego terminu oceny porównawczej zmienili obraz ówczesnej estetyki, zrywając częściowo z popularną wówczas tendencją psychologizacji smaku i irracjonalnym nastawieniem. 
Burke Edmund. 1968. Dociekania filozoficzne o pochodzeniu naszych idei wzniosłości i piękna, przeł. Piotr Graff. Warszawa: PWN.

Dickie George. 1996. The Century of Taste. The Philosophical Odyssey of Taste in the Eighteenth Century. New York-Oxford: Oxford University Press.

Gerard Alexander. 1774. An Essay on Genius. London-Edinburgh: W. Strahan; T. Cadell.

Gerard Alexander. 1780. An Essay on Taste to which is now added part fourth, Of the Standard of Taste, 3rd edition. London: J. Bell and W. Creech, Edinburgh: T. Cadell.

Gerard Alexander. 1997. „Esej o guście”, fragmenty, przeł. Zofia Sinko. W: Europejskie źródła myśli estetyczno-literackiej polskiego oświecenia. Antologia wypowiedzi pisarzy francuskiego, niemieckiego i angielskiego obszaru językowego. 1674-1810, red. Teresa Kostkiewiczowa, Zbigniew Goliński. Warszawa: Semper.

Grzeliński Adam. 2001. Angielski spór o istotę piękna. Koncepcje estetyczne Shaftesbury'ego i Burke'a. Toruń: Wydawnictwo Adam Marszałek.

Hipple Walter. 1957. The Beautiful, the Sublime, and the Picturesque in Eighteenth-Century British Aesthetic Theory. Carbondale: The Southern Illinois University Press.

Hume David. 1955. „Sprawdzian smaku”. W: David Hume, Eseje z dziedziny moralności i literatury, przeł. Teresa Tatarkiewiczowa. Warszawa: PWN.

Kivy Peter. 1976. The Seventh Sense. A Study of Francis Hutcheson's Aesthetics And Its Influence in Eighteenth-Century Britain. New York: Burt Franklin \& Co.

Locke John. 1955. Rozważania dotyczace rozumu ludzkiego, przeł. Bolesław Józef Gawecki. Kraków: PWN.

Monk Samuel. 1960. The Sublime: A Study of Critical Theories in XVIII-Century England. Ann Arbor: University of Michigan Press.

Morawski Stefan. 1961. „O podstawowych zagadnieniach estetyki angielskiej XVIII w.". Studia z historii myśli estetycznej XVIII i XIX w. Warszawa: PWN.

Pazura Stanisław. 1981. De gustibus. Rozważania nad dziejami pojęcia smaku estetycznego. Warszawa: PWN.

Śliwa Marta. 2009. Teoria piękna w filozofii Francisa Hutchesona. Olsztyn: UWM.

Śliwa Marta. 2018. „Philosophical Societies in the Scottish Enlightenment”. Ruch Filozoficzny LXXIV, 3: 107-117.

Wawrzonkowski Krzysztof. 2009 Smak, geniusz, sztuka. Filozofia piękna Alexandra Gerarda w świetle estetyki kantowskiej. Toruń: WN UMK.

Wawrzonkowski Krzysztof. 2010. Wyobraźnia i wzniosłość. Teoriopoznawcze podstawy wybranych brytyjskich koncepcji estetycznych XVIII wieku. Toruń: TAKO.

Wawrzonkowski Krzysztof. 2016. „Alexander Gerard's Correction of Hume's Standard of Taste". W: Вісник НАУ. Серія: Філософія. Культурологія, Збірник наукових працьь, Київ, 6-11.

Wawrzonkowski Krzysztof. 2016. „Dobre towarzystwo - rozwój smaku estetycznego w dobie Oświecenia". W: Znaczenie filozofii Oświecenia. Czło- 
wiek wśród ludzi, red. Barbara Grabowska, Adam Grzeliński, Jolanta Żelazna. Toruń: WN UMK.

Zabieglik Stefan. 1997. „Wiek doskonalenia. Z filozofii szkockiego oświecenia". Zeszyty naukowe Politechniki Gdańskiej, Filozofia III, 558.

\section{Streszczenie}

Niniejszy artykuł poświęcony jest koncepcji estetycznej Gerarda i roli, jaką przewidział on w niej dla rozumu (ratio) i wydawanych przez niego sądów (judgments). Dla lepszego zrozumienia doniosłości i znaczenia rozważań filozofa przedstawiam je w szerszym kontekście na tle osiemnastowiecznej estetyki brytyjskiej. Podejmuję tu przede wszystkim kwestie związane ze smakiem estetycznym, jego składowymi, sposobem funkcjonowania i rolą rozumu w orzekaniu sądów estetycznych. Wskazuję również na rolę, jaką Gerard przewidział dla rozumu w twórczej pracy geniuszu.

Słowa kluczowe: Alexander Gerard, smak estetyczny, geniusz, rozum, sąd, osiemnastowieczna estetyka brytyjska

\section{The Role of Reason in Alexander Gerards's Aesthetics}

\section{Summary}

This article is devoted to Gerard's aesthetic concept and the role he envisaged in it for reason (ratio) and judgments. For a better understanding of the importance and significance of the philosopher's considerations, I present them in a broader context against the background of the $18^{\text {th }}$-century British aesthetics. Here, I am primarily concerned with issues related to aesthetic taste, its components, the way it functions, and the role of reason in making aesthetic judgments. I also point to the role which Gerard envisaged for reason in the creative work of genius.

Keywords: Alexander Gerard, aesthetics taste, genius, reason, ratio, judgment, $18^{\text {th }}$-century British aesthetics 